\title{
The Effect of Assessment for Learning Integration in Scientific Approach Towards Students' Conceptual Understanding on Work and Energy
}

\author{
Nur Elisa, Sentot Kusairi *, Sulur Sulur, Ahmad Suryadi \\ Department of Physics, Faculty of Mathematics and Natural Sciences, Universitas Negeri Malang \\ Jalan Semarang No. 5 Malang, 65145, Indonesia \\ *Corresponding author. Email: sentot.kusairi.fmipa@um.ac.id
}

\begin{abstract}
This study aims to determine the effect of the integrated assessment for Learning (AfL) which is assisted by the Tryout application in scientific approach on students' conceptual understanding. This study used a quasi-experimental method with a pretest-posttest control group design. This research was conducted at a high school in Malang with a sample of two classes by a random cluster sampling technique. There were two classes involved, namely one as an experimental class (using an integrated AfL assisted with a tryout application in scientific approach) and one as a control class (using a scientific approach through assignment instructions). Thirthy four students in each class were tough the work and energy topic. The test instrument used was 20 reasoned multiple-choice questions with a reliability of 0.62 . Data were analyzed using descriptive analysis and inferential statistics. The results showed that there was a significant difference between the posttest mean scores of the experimental class students and the control class students $(p=0.017)$. Descriptive analysis showed that the mean scores of posttest students for the experiment and control class were 61.76 and 54.26, respectively. That means that the conceptual understanding of students who learn with integrated AfL that assisted by tryout application in scientific approach was higher than students who learn with the scientific approach through assignments.
\end{abstract}

Keywords: assessment for Learning (AfL); conceptual understanding; scientific approach; work and energy.

\section{Introduction}

The most important competency in learning physics is the ability to understand the concepts. Good conceptual understanding can make students fully understand concepts, principles, or laws of physics without having to memorize them (Sakti, 2013). It can also help students to develop their existing comprehension into more complete knowledge (Nurmalasari, Kade, \& Kamaluddin, 2014). One of the physical topics that must be understood well by students is work and energy. Work and energy topics are very important to be understood by students because they relate to problems with motion in daily life (Subagya, 2016).

Some studies indicated that the understanding of the work and energy concepts was still low even some students had misconceptions (Oktavia, Sulaeman, \& Komariyah, 2017; Rahmatina, Sutopo, \& Wartono, 2018; Zafitri, Fitriyanto, \& Yahya, 2018). Some researchers had made efforts to improve the understanding of the work and energy concepts, including by applying PhET-assisted conceptual learning to support students' understanding of work and energy concepts deeply (Patriot, Suhandi, \& Chandra, 2018; Podschuweit \& Bernholt, 2018). However, they have to pay attention to the allocation of time because the steps during learning require considerable time. Peters (2012) and Santoso \& Mutmainna (2018) also provided that information based learning Nature of Science (NOS) was able to improve the students'

\section{How to Cite:}

Elisa, N., Kusairi, S., Sulur, S., \& Suryadi, A. (2019). The Effect of Assessment for Learning Integration in Scientific Approach Towards Students' Conceptual Understanding on Work and Energy. Momentum: Physics Education Journal, 3(2), 103-110. https://doi.org/10.21067/mpej.v3i2.3761 
knowledge on the matter of work and energy. However, more efforts are still needed to implement NOS instructions because the learning and assessment process requires a long time.

Based on the facts above, appropriate efforts are needed to overcome the lack of understanding of work and energy concepts. One of them was by applying a scientific learning approach, which in its implementation really involves the active role of students (student center) (Marjan, Arnyana, \& Setiawan, 2014). The scientific approach is learning that consists of five scientific processes namely observing, asking questions, exploring, associating, and presenting (In'am \& Hajar, 2017). The scientific process in studying scientific approaches can improve students' understanding and activeness to find concepts independently of the topic being studied (Ramdhani, Usodo, \& Subanti, 2017).

In addition to learning techniques, complementary aspects of learning are needed that can be used as identification of students' difficulty. AfL is an assessment conducted at all times during the learning process (Earl, 2007). The implementation of AfL is focused on providing feedback that can help students to identify concepts very well (Diyanahesa, Kusairi, \& Latifah, 2017; Lorente-Catalán \& Kirk, 2016). Providing feedback during the implementation of AfL directly could improve student motivation in learning (Thanh Pham \& Renshaw, 2015). In addition, Giving direct feedback was more useful than feedback that done in a simple (conventional) and the impact on student achievement (Meier et al., 2016).

Feedback can be done quickly and precisely with the help of the web-based application. The possible application to be used is the tryout application developed by Kusairi (2013). Tryout application developed with the aim to give individual feedback to students, so that students could perform a self-assessment to monitor the progress of learning activities. The explanations show that the scientific approach has the potential to be improved by integrating assessment for learning. Unfortunately, the optimization of scientific learning through the use of AfL has not yet been done. This study aims to compare students' understanding of the concepts taught by using the AfL integrated scientific approach aided by the tryout application with the scientific approach that uses assignments.

\section{Method}

This study used a quasi-experimental method with a pretest-posttest control group design. The design of the research design can be seen in Table 1.

Table 1. Design of Pretest-Posttest with Control Group Design

\begin{tabular}{cccc}
\hline Group & Pre-test & Treatment & Post-test \\
\hline Experiment & $\mathrm{O}_{1}$ & $\mathrm{X}_{\mathrm{K}}$ & $\mathrm{O}_{2}$ \\
Control & $\mathrm{O}_{3}$ & $\mathrm{X}_{\mathrm{K}}$ & $\mathrm{O}_{4}$ \\
\hline
\end{tabular}

(Sugiyono, 2009)

$\mathrm{O}_{1}=$ score of pretest for the experimental class before being given treatment.

$\mathrm{O}_{2}=$ score of posttest for the experimental class after being treated.

$\mathrm{O}_{3}=$ score of pretest for the control class before being given treatment.

$\mathrm{O}_{4}=$ score of posttest for the control class after being treated.

$X_{E}=A f L$ treatment with the help of the tryout application (TO).

$X_{K}=A f L$ treatment through assignment.

The study was conducted at one of the senior high school in Malang. There were 34 students in the experiment and the control class exactly. The determination of the sample study was conducted using a random cluster sampling technique (Sugiyono, 2016). Treatment of the studies was using a syllabus, lesson plan, and students worksheet. They were designed by five scientific processes in the scientific approach of observing, questioning, exploring, associating, and communicating. These 5 scientific process activities were then integrated with AfL and then each student was observed by measuring students' conceptual understandings. Broadly speaking, the implementation of the scientific approach instruction integrated to AfL presented through the diagram in Figure 1. 


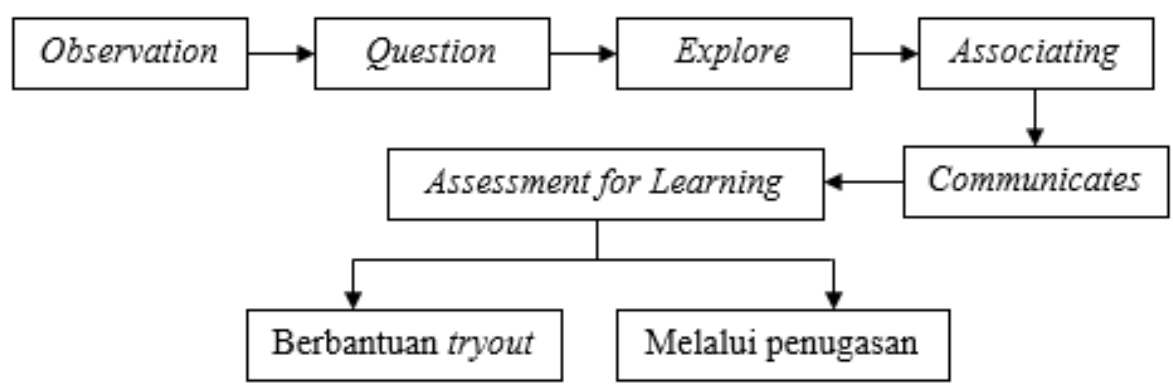

Figure 1. Diagram of Scientific Approach instruction Integrated AfL

In the observation process, students were shown demonstration videos or phenomena related to effort and energy not only to build students' initial knowledge but also to train students to explore some information based on the phenomenon displayed. The next process was questioning, the students were given the opportunity to ask questions based on their observations of physical phenomena by the teacher. Through this process, students learn to formulate problems and develop curiosity. In the process of exploring, students collecting data based on observation or conducting experimental activities, this process aims to improve student accuracy and ability to gather information in various ways. In the process of associating, students did problems analysis using concepts, this process help students in applying concepts that had been learned and build students' ability to draw conclusions. The last process was questioning, students present what had been obtained. Students' ability to communicate and respect the opinions of other groups would be trained through this process.

Learning in the experimental class and control class was done by using a similar lesson plan. In the experimental class, the learning was a scientific approach integrated with AfL with the application of tryout, while the control class using the scientific approach through assignment or still being done conventionally. The experimental class would be given direct feedback through AfL. The tryout application can provide feedback in the form of scores and diagnostic scores for each indicator. Therefore, students could immediately improve and deepen the topic on indicators that had not yet been reached as well as improvement of learning at the next meeting. Figure 2 shows the feedback given to students.

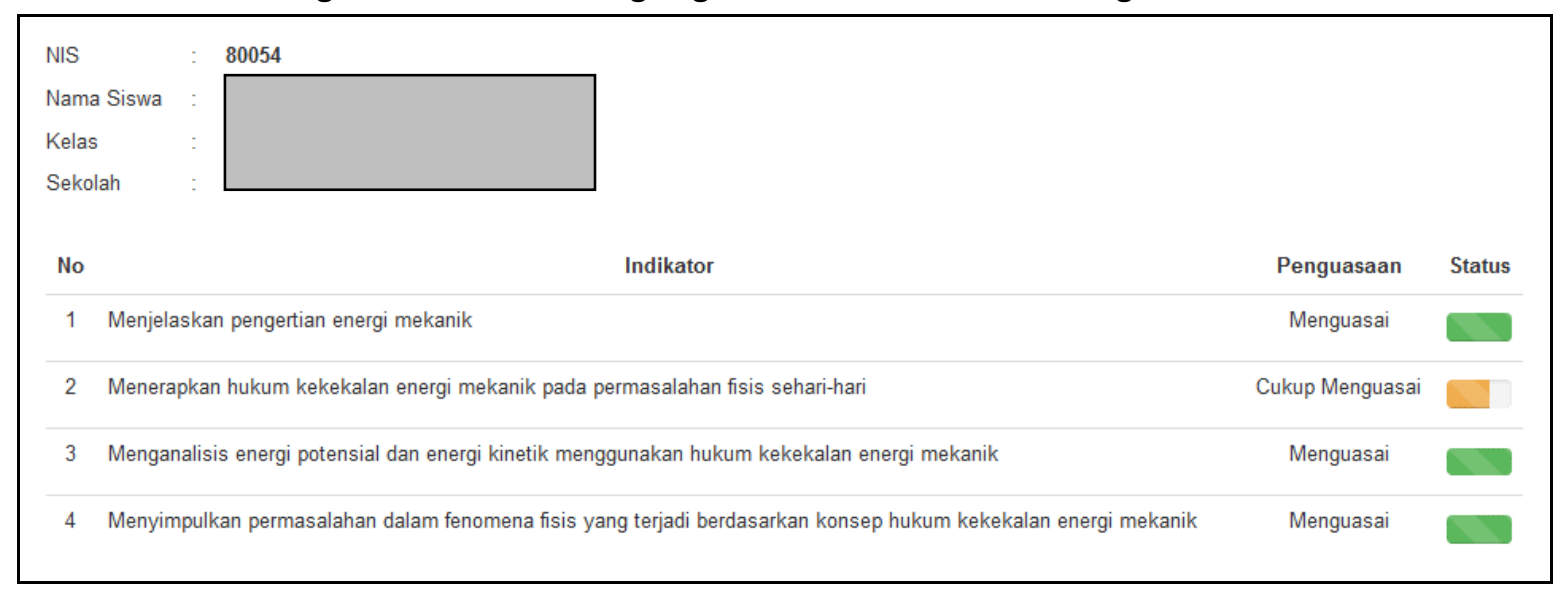

Figure 2. Feedback for students on tryouts 3 display

The tryout application also provided feedback to the teachers. Feedback for teachers is in the form of a percentage of students' conceptual understandings in each indicator. Figure 3 shows the display of feedback given to teachers.

Figure 3 shows the percentage of one class conceptual understanding. In addition to the percentage on each indicator, the teacher also gets information in the form of the percentage of students' answers. The teacher was easier to find out students' difficulties with the topic being studied. The follow-up feedback was done by discussing the questions that had the largest percentage of wrong answers, followed 
by discussing other questions that students ask. Whereas AfL in the control class giving feedback takes a long time. This was because the teacher needs time to correct and analyze student work. Students find it difficult to know where they lack themselves.

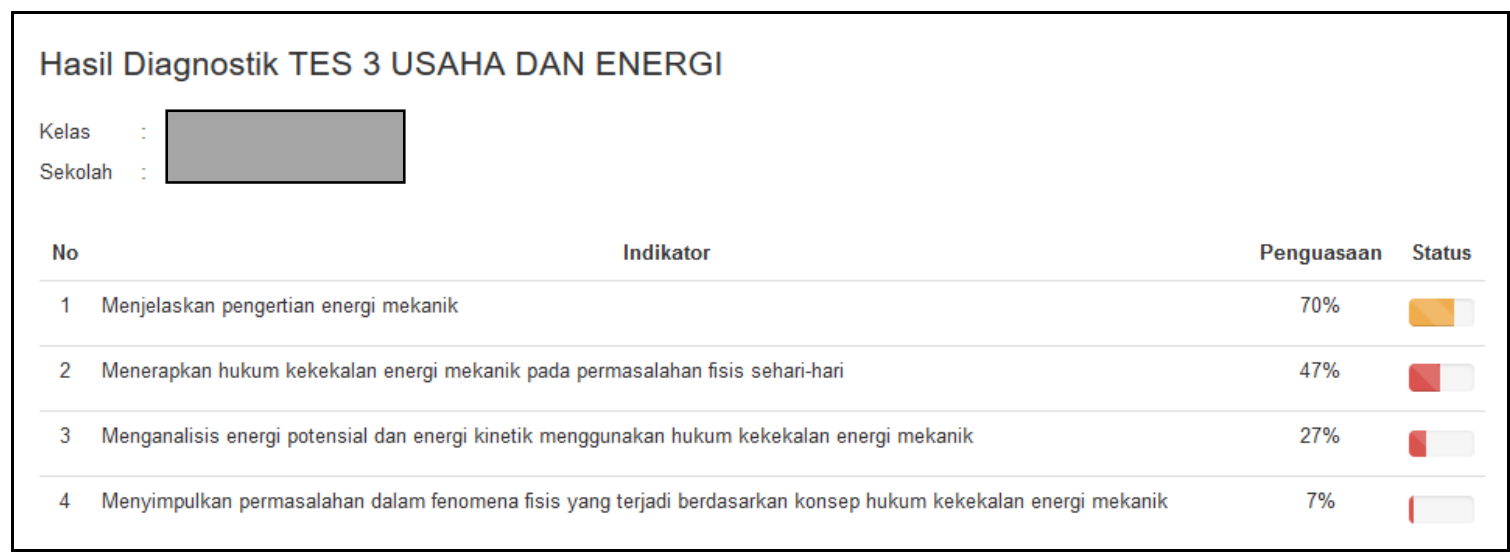

Figure 3. Display Feedback for Teachers on Tryout 3

The instrument to measure this research was a reasoned multiple-choice test that consists of 24 questions originally. The question instrument was developed from the results of previous researchers namely Ding, Chabay, \& Sherwood (2013); Hestenes \& Wells (1992); Rahmatina et al. (2018); and Singh \& Rosengrant (2003). Through the validity test, there were 20 questions valid with reliability of 0.622 . The cognitive level of the question set from C2 to C4. Tests given to both classes were identical pretest and posttest. The conceptual understanding test questions per indicator can be seen in Table 2 .

Table 2. The indicators of conceptual understanding questions

\begin{tabular}{lc}
\hline \multicolumn{1}{c}{ Indicator Competency Achievement } & Item number \\
\hline 3.9.2 Explain the concept of work & 1.2 \\
3.9.3 Determine the amount of effort done by an object & $3,4,5$ \\
3.9.4 Analyze the graph of the relationship of force and displacement to large work & 6 \\
3.9.6 Explain the general concept of energy & $7,9,15$ \\
3.9.8 Determine the amount of energy (potential and kinetic) of an object & 16 \\
3.9.9 Analyze the amount of energy (potential and kinetic) of an object & 11 \\
3.9. 11 Explain the relationship between effort and energy (kinetic and potential) & 8.13 \\
3.9.12 Determine the relationship of work with energy (kinetic and potential) & $10.17,12$ \\
3.9.13 Analyzing the relationship between effort and energy (kinetic and potential) & 14 \\
3.9.14 Explain the concept of mechanical energy and the law of conservation of mechanical energy & 18 \\
3.9.16 Determine the amount of energy based on the law of conservation of mechanical energy & 20,21 \\
3.9.17 Analyze the form of mechanical energy law in everyday life. & $19,22,23,24$ \\
\hline
\end{tabular}

The data were analyzed by descriptive analysis and inferential statistics. Descriptive analysis was used in the form of minimum value, maximum value, mean, and standard deviation. Inferential statistics use the Shapiro Wilk test for normality tests, Levene statistics for homogeneity tests, and independent ttests for initial ability tests and hypothesis testing.

\section{Result and Discussion}

Students' conceptual understanding score of pretest and posttest in the experimental class and control class are presented in Table 3.

Table 3. Descriptive analysis of students conceptual understanding

\begin{tabular}{clccccc}
\hline \multicolumn{2}{c}{ Source of Variation } & Total Students & Mean & Standard Deviation & Maximum & Minimum \\
\hline \multirow{2}{*}{ pretest } & Control Class & 34 & 25.88 & 14.88 & 50.00 & .00 \\
& Experiment Class & 34 & 26.76 & 15.22 & 55.00 & .00 \\
posttest & 34 & 54.26 & 14.67 & 80.00 & 25.00 \\
& control class & 34 & 61.76 & 14.03 & 90.00 & 30.00 \\
\hline
\end{tabular}


Based on Table 3, obtained data showing a significant difference from the average value of pretest and posttest experimental class and control class. First, before conducting an inferential test, the assumption test had been run. The normality and homogeneity test results showed that the data were normally distributed and homogeneous. The independent sample t-test assumption had been met. The result of independent $\mathrm{t}$-test between pretest score of experiment and control class showed that $(2$-tailed) $=$ $0.810>0.05$ or $\mathrm{t}_{\text {arithmetic }}=0.242<\mathrm{t}_{\text {table }}=1.998$, which means both classes have the same initial ability. Furthermore, the data posttest was tested by using an independent sample t-test curve one-tailed, the average value of the posttest the experimental class was better than the control class, and it was obtained by Sig. (1-tailed) $=0.0175<0.05$ or $\mathrm{t}_{\text {arithmetic }}=2.154>\mathrm{t}_{\text {table }}=1.669$. This shows that the conceptual understanding of the experimental class and the control class were different significantly.

Students' conceptual understanding can be seen based on the percentage of students' conceptual understandings per subtopic. It shows in Table 4.

Table 4. Percentage of Mastery Concept Results Per Sub-Topic

\begin{tabular}{|c|c|c|c|}
\hline \multirow{2}{*}{ Source Variance } & \multirow{2}{*}{ Sub-Topic } & \multicolumn{2}{|c|}{ Presentation (\%) } \\
\hline & & Pretest (\%) & Posttest (\%) \\
\hline \multirow[t]{3}{*}{ Experiment Class } & Work Concept & $53 \%$ & $84 \%$ \\
\hline & Energy Concepts and Work Relations with Energy & $27 \%$ & $58 \%$ \\
\hline & Law of Conservation of Mechanical Energy & $5 \%$ & $50 \%$ \\
\hline \multirow[t]{3}{*}{ Control Class } & Work Concepts & $71 \%$ & $73 \%$ \\
\hline & Energy Concepts and Work Relations with Energy & $19 \%$ & $48 \%$ \\
\hline & Law of Conservation of Mechanical Energy & $7 \%$ & $49 \%$ \\
\hline
\end{tabular}

In the experimental class, one of the problems where students had difficulty giving reasons for answers lies in question number 10. It was about determining the relationship between work and energy. Students were required to determine the amount of effort on a moving object with a speed v. Question number 10 and the percentage of students' answers during the pretest and posttest presented in Figure 4.

A box with mass $m$ moves with velocity $v$ along a slippery surface toward Nia. Nia leaned against the wall with both hands forward to stop the box.

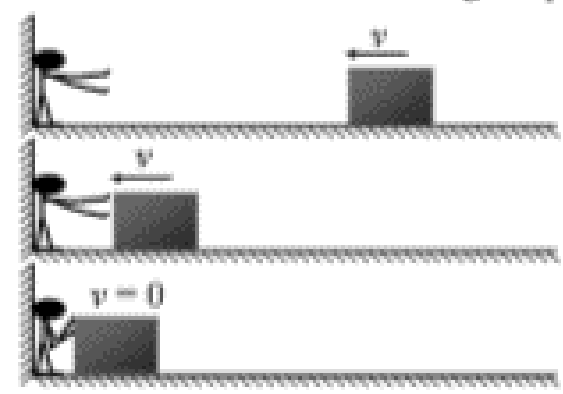

During the process, the amount of effort that Nia did on the box was ...

a.the work that she did on the box was $\frac{1}{2} \mathrm{mv}^{2}$ (Pretest (29\%); Posttest (11\%))

b. the work done by Nia on the box is $-\frac{1}{2} \mathrm{mv}^{2}$ (Pretest (24\%); Posttest (53\%))

c. the work done by Nia on the box is zero (Pretest (29\%); Posttest (24\%)) the

d. the work done by Nia on the box is $\mathrm{mv}^{2}$ (Pretest (0\%); posttest (6\%))

e.the work done by Nia on the box is $-\mathrm{mv}^{2}$ (Pretest (0\%); Posttest (3\%))

No answer (Pretest (18\%); Posttest (3\%))

(Ding et al., 2013)

Figure 4. Question number 10 
During the pretest, most students choose options a and c which were wrong answers, and when posttest $53 \%$ of students choose option b which was the correct answer. However, based on the reasons given by the students, most of the students still could not give reasons using the mathematical formula, only 2 students (6\%) could give reasons based on the mathematical concept and formulation of the work and kinetic energy relationship.

In the control class, one of the problems where students had difficulty in giving reasons for answers lies in problem number 19. The indicator was analyzing the form of the law of conservation of mechanical energy in daily life. Students were asked to analyze the velocity of objects when they were at the same height. Question number 10 and the percentage of students' answers during the pretest and posttest presented in Figure 5.

Disa wants to choose one of the slides in the playground as shown below.

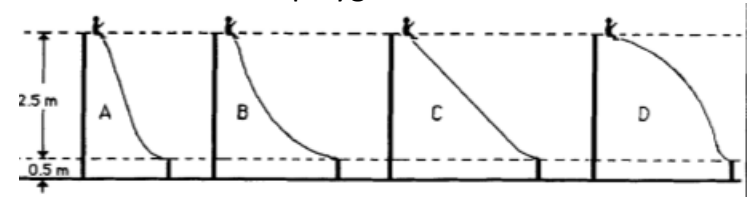

The slides illustrated in the diagram above should Disa choose is ...

a. slide B (Pretest (3\%); Posttest (0\%))

b.Slide C (Pretest (6\%); Posttest (6\%))

c. Slide D (Pretest ( 0\%); Posttest (0\%))

d.all slides have the same speed (Pretest (3\%); Posttest (79\%))

No Answer (Pretest (12\%); Posttest (3\%))

(Hestenes \& Wells, 1992)

Figure 5. Question number 19

At pretest, most students choose option a which was the wrong answer, and when posttest $79 \%$ of students choose option e which was the correct answer. But based on the reasons given by students, some students still cannot provide reasons for using the mathematical formula. Students also still think that Disa's speed to get to the bottom depends on the speed, the steeper the Disa track would get to the bottom faster.

\section{Conclusion}

Based on the results of data analysis and discussion, it was concluded that the mastery of the concept of work topic and energy of the experimental class was higher than the control class. The results of this study indicate that the scientific approach integrated AfL aided by application tryout affects the ability of students to understand concepts. Even though the data shows a significant difference, the average value of the results of the posttest of the two classes was still below the subject score threshold which was 61.76 in the experimental class and 54.26 in the control class. The results of this study were still need to improved. One of the factors was the limited use of technology used during learning activities. In addition, researchers cannot utilize the tryout application optimally, in the form of the use of web voting during the implementation of feedback further.

\section{References}

Ding, L., Chabay, R., \& Sherwood, B. (2013). How do students in an innovative principle-based mechanics course understand energy concepts?: ASSESSING M\&I STUDENTS' ENERGY CONCEPTIONS. Journal of Research in Science Teaching, 50(6), 722-747. https://doi.org/10.1002/tea.21097

Diyanahesa, N. E.-H., Kusairi, S., \& Latifah, E. (2017). Development of misconception diagnostic test in momentum and impulse using isomorphic problem. Journal of Physics: Theories and Applications, 1(2), 145-156. https://doi.org/10.20961/jphystheor-appl.v1i2.19314 
Earl, L. (2007). Assessmentâ?””a powerful lever for learning. Brock Education Journal, 16(1). https://doi.org/10.26522/brocked.v16i1.29

Hestenes, D., \& Wells, M. (1992). A mechanics baseline test. The Physics Teacher, 30(3), 159-166. https://doi.org/10.1119/1.2343498

In'am, A., \& Hajar, S. (2017). Learning geometry through discovery learning using a scientific approach. International Journal of Instruction, 10(01), 55-70. https://doi.org/10.12973/iji.2017.1014a

Kusairi, S. (2013). Analisis asesmen formatif fisika sma berbantuan komputer. Jurnal Penelitian Dan Evaluasi Pendidikan, 16, 68-87. https://doi.org/10.21831/pep.v16i0.1106

Lorente-Catalán, E., \& Kirk, D. (2016). Student teachers' understanding and application of assessment for learning during a physical education teacher education course. European Physical Education Review, 22(1), 65-81. https://doi.org/10.1177/1356336X15590352

Marjan, J., Arnyana, I. B. P., \& Setiawan, I. G. A. N. (2014). Johari Marjan (2014). Pengaruh pembelajaran pendekatan saintifik terhadap hasil belajar biologi dan keterampilan proses sains siswa MA Mu'allimat NW Pancor Selong Kabupaten Lombok Timur Nusa Tenggara Barat. e-Journal Program Pascasarjana Universitas Pendidikan Ganesha, 4.

Nurmalasari, R., Kade, A., \& Kamaluddin, K. (2014). Pengaruh model learning cycle tipe $7 E$ terhadap pemahaman konsep fisika siswa kelas VII SMP Negeri 19 Palu. JPFT (Jurnal Pendidikan Fisika Tadulako Online), 1(2), 18. https://doi.org/10.22487/j25805924.2013.v1.i2.2389

Oktavia, P., Sulaeman, N. F., \& Komariyah, L. (2017). Analisis penguasaan konsep usaha dan energi menggunakan certainty of response index (CRI)di SMA Negeri 3 Samarinda. Prosiding Seminar Nasional Pendidikan IPA, 27-37. Palembang: Universitas Brawijaya.

Patriot, E. A., Suhandi, A., \& Chandra, D. T. (2018). Optimize scientific communication skills on work and energy concept with implementation of interactive conceptual instruction and multi representation approach. Journal of Physics: Conference Series, 1013, 012029. https://doi.org/10.1088/17426596/1013/1/012029

Peters, E. E. (2012). Developing content knowledge in students through explicit teaching of the nature of science: Influences of goal setting and self-monitoring. Science \& Education, 21(6), 881-898. https://doi.org/10.1007/s11191-009-9219-1

Podschuweit, S., \& Bernholt, S. (2018). Composition-effects of context-based learning opportunities on students' understanding of energy. Research in Science Education, 48(4), 717-752. https://doi.org/10.1007/s11165-016-9585-z

Rahmatina, D. I., Sutopo, \& Wartono. (2018). Identifikasi kesulitan siswa SMA pada materi usaha-energi. Momentum: Physics Education Journal, 2(1), 8-14.

Ramdhani, M. R., Usodo, B., \& Subanti, S. (2017). Discovery learning with scientific approach on geometry. Journal of Physics: Conference Series, 895, 012033. https://doi.org/10.1088/17426596/895/1/012033

Sakti, I. (2013). Pengaruh media animasi fisika dalam model pembelajaran langsung (direct instruction) terhadap minat belajar dan pemahaman konsep fisika siswa di SMA Negeri Kota Bengkulu. Prosiding Semirata FMIPA Universitas Lampung, 493-498.

Santoso, P. H., \& Mutmainna, M. (2018). Pembelajaran fisika berbasis nature of science (nos) untuk meningkatkan pemahaman konsep fisika peserta didik. PHYDAGOGIC Jurnal Fisika Dan Pembelajarannya, 1(1), 15-23. https://doi.org/10.31605/phy.v1i1.209

Singh, C., \& Rosengrant, D. (2003). Multiple-choice test of energy and momentum concepts. American Journal of Physics, 71(6), 607-617. https://doi.org/10.1119/1.1571832

Subagya, H. (2016). Konsep dan penerapan Fisika SMA/MA Kelas X. Jakarta: PT Bumi Aksara.

Sugiyono. (2009). Metode Penelitian Kualitatif, Kuantitatif dan R\&D. Bandung: Alfabeta.

Thanh Pham, T. H., \& Renshaw, P. (2015). Formative assessment in Confucian heritage culture classrooms: Activity theory analysis of tensions, contradictions and hybrid practices. Assessment \& Evaluation in Higher Education, 40(1), 45-59. https://doi.org/10.1080/02602938.2014.886325 
Zafitri, R. E., Fitriyanto, S., \& Yahya, F. (2018). Pengembangan tes diagnostik untuk miskonsepsi pada materi usaha dan energi berbasis adobe flash kelas XI di MA NW samawa Sumbawa Besar tahun ajaran 2017/2018. Jurnal Kependidikan, 2(2), 19-34. https://doi.org/10.31227/osf.io/7wyx6 